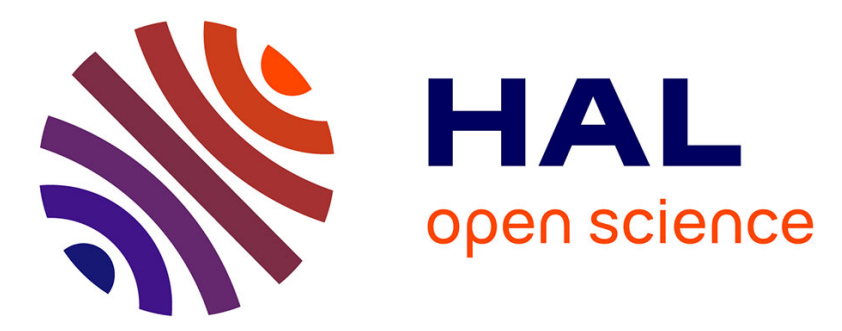

\title{
Application of utilizability computation methods to Europe and Africa
}

\author{
Maria Joao Carvalho, Bernard Bourges
}

\section{To cite this version:}

Maria Joao Carvalho, Bernard Bourges. Application of utilizability computation methods to Europe and Africa. Intersol Eighty Five, Pergamon, pp.2439-2443, 1986, 9780080331775. 10.1016/B978-008-033177-5.50459-2 . hal-00949145

\section{HAL Id: hal-00949145 \\ https://hal.science/hal-00949145}

Submitted on 6 Jul 2021

HAL is a multi-disciplinary open access archive for the deposit and dissemination of scientific research documents, whether they are published or not. The documents may come from teaching and research institutions in France or abroad, or from public or private research centers.
L'archive ouverte pluridisciplinaire HAL, est destinée au dépôt et à la diffusion de documents scientifiques de niveau recherche, publiés ou non, émanant des établissements d'enseignement et de recherche français ou étrangers, des laboratoires publics ou privés. 


\title{
APPLICATION OF UTILIZABILITY COMPUTATION METHODS TO EUROPE AND AFRICA
}

\author{
+ * \\ Maria JOAO CARUALHO and Bernard BOURGES \\ + Laboratorio Nacional de Engenharia e Tecnologia Industrial, Lisboa \\ * Centre d’Energétique, Ecole des Mines de Paris
}

\begin{abstract}
Some methods for computing solar energy utilizability are applied to European and African locations and compared with actual values obtained from long-term measurements on horizontal and south-oriented tilted planes. Most of analyzed methods give acceptable results (within $20 \%$ ) when the actual monthly average daily irradiation on the considered surface is known. When this value is not known (i.e. computed from monthly mean on a horiz. plane), errors on the monthly available energy above a threshold irradiance may be in the range $30-40 \%$.
\end{abstract}

\section{KEYWORDS}

Solar radiation; utilizability; tilted planes; design methods.

\section{INTRODUCTION}

Utilizability has now become an usual meteorological input for a number of simplified design methods of solar systems (thermal active, passive, photovoltaic). Various methods for the computation of solar energy utilizability have been pubiished in the former years $(1-6)$ and reviewed recently (7). Some characteristics are general to these methods: most of them are derived from North -American radiation data; solar radiation on tilted planes is computed through the usual and so-called "isotropic" assumption for diffuse sky radiation. It is now possible to question both assumptions, as radiation data have become available for other climates (e.g. Europe and Africa) and for tilted planes. Objectives of the present study were, first, to apply the selected Utilizability methods to some sample of representative meteorological stations and, second, to compare results with values directly obtained by analyzing hourly files of measured solar radiation, on a horizontal plane and on tilted planes.

\section{UTILIZABILITY AND AVAILABLE ENERGY}

Solar system design can be done by simplified methods which need, as input for the calculation of solar fraction, the long-term energy delivery of the system at different thresholds. These computations are based on the concept of 
"Utilizability" defined as $\varnothing(1 s)=\int_{\Delta t}(1-1 c)+$. dt $/{ }^{n} H_{T}$

The Utilizability $\theta(I C)$ is the fraction of solar radiation $\mathrm{nH}_{\mathrm{H}}$ incident upon a collector's aperture during a certain period $\Delta t$ (month or year), that lies above the specific threshold irradiance $I f$. The product $B$. nHt is sometimes called the "available solar energy above the threshold Ic" (for the period).

\section{UTILIZABILITY CALCULATION METHODS}

Various methods have been published for utilizability computation and reviewed recertiy (7). Six of these methods have been considered in the presens work $(1-6)$. The first four methods only need as climatological input the mean daily 9lobal radiation value on a horizontal plane, $H_{H}$, and on the collector plane, $H_{T}$ (This last value may be also computed from $H_{H}$ with method ( 8 ), if it is not $k$ in). They have been derived as $f i t s$ to North-American data us the "clearness index" $K_{T}=H_{H} / H_{0}$ which is the parameter used to indicate the dependence of $\nabla$ with $c$ limate. The two last methods require an additionnal parameter Imax. maximal irradiance on the considered plane.

Collares-Pereira.Rabl method (1) includes in the same step computations of $\varnothing$ and $H_{T}$ from $H_{H}$; it is also suitable for concentrating collectors. Clark's method (2) is the only hourly-based utilizability method. Evans method (3) oroposes three different correlations of 8 suitable for flat-plate solar collectors: on ly one of them is reported here, after transformation into function of It and $K_{T}{ }^{\prime}$ (related to $K_{T}$ )

$$
\theta=1-1.07 .10^{-3} \cdot 1.1 K_{T^{\prime}}+3.02 .10^{-1},\left(1 \mathrm{I}_{\mathrm{r}} / \mathrm{K}_{T^{\prime}}\right)^{2}
$$

Gordon and 2 armi's method (5) is an analytical approach to the Utilizability concept, with the semi-empirical form for flate-plate collector

$$
\theta(I 0)=\left(1-i c / I_{\text {MaX }}\right) \text { ily }
$$

with: $1 / y=I_{M A x} t_{0} ; H_{T}$ and $t_{0}$ is the time between sunrise and sunset. In method (6), "utilizability" is derived from Cumulative Frequency Curves (CFC) of solar irradiance incident on the collector. CFC's are defined as curwes giving the time $n_{n}$ (mean daily number of hours) during which the solar radiation is above some threshold ic. Correlations have been developed from a Principal Components Factor Analysis to give the Coefficients of a 5 TH order poiynomial CFC fitting from the parameter $v=H_{r}\left(\right.$ imax $\left._{0} t_{0}\right)$.

\section{AUAILABLE DATA ANO METHODOLOGY}

Solar radiation data used in the oresent analysis are summarized in Table 1. Three to seven years of solar global radiation measured hourly values have been collected for horizontal planes or south-oriented tilted planes (without ground-reflected diffuse radiation).

\begin{tabular}{|c|c|c|c|c|c|c|}
\hline Station & Country & Tilt & Latitude & Longi tude & Altitude & Period \\
\hline ire & France & $0^{\circ}$ & $43.7 \cdot \mathrm{N}$ & 7.2 & $10 \mathrm{~m}$ & 19 \\
\hline lau & France & $8^{\circ}$ & $44.1{ }^{\circ} \mathrm{N}$ & $3.0 . E$ & $720 \mathrm{~m}$ & $1970-75$ \\
\hline Carpentras & France & $\begin{array}{c}0^{\circ} \\
45^{\circ}-90^{\circ}\end{array}$ & 44. & 5. & $99 \mathrm{~m}$ & $\begin{array}{l}1970-75 \\
1979-81\end{array}$ \\
\hline $\begin{array}{l}\text { Lisboa } \\
\text { Trappes }\end{array}$ & $\begin{array}{l}\text { Portugal } \\
\text { France }\end{array}$ & $\begin{array}{c}0^{\circ} \\
0^{\circ} \\
45^{\circ}-90^{\circ}\end{array}$ & $\begin{array}{l}38.7^{\circ} \mathrm{N} \\
48.8^{\circ} \mathrm{N}\end{array}$ & $\begin{array}{l}9.1 \cdot \mathrm{W} \\
2.0 \cdot \mathrm{E}\end{array}$ & $\begin{array}{r}77 \mathrm{~m} \\
167 \mathrm{~m}\end{array}$ & $\begin{array}{l}1975-77 \\
1970-75 \\
1979-81\end{array}$ \\
\hline $\begin{array}{l}\text { Kilkenny } \\
\text { Maputo }\end{array}$ & $\begin{array}{c}\text { Ireland } \\
\text { Mozambi que }\end{array}$ & $\begin{array}{l}0^{\circ} \\
0^{\circ}\end{array}$ & $\begin{array}{l}52.7^{\circ} \mathrm{N} \\
25.9 \cdot \mathrm{S}\end{array}$ & $\begin{array}{r}7.3^{\circ} \mathrm{W} \\
32.6^{\circ} \mathrm{E}\end{array}$ & $\begin{array}{l}64 \mathrm{~m} \\
44 \mathrm{~m}\end{array}$ & $\begin{array}{l}1969-75 \\
1965-69\end{array}$ \\
\hline
\end{tabular}

Tabie 1: Solar Radiation Data Lsed in the Present Analysis 
Ava i lable datamaybe combined in three groups:

1. Southern Europe (Nice, Carpentras, Millau, Lisboa)

2. Northern Europe (Trappes, Kilkenny)

3. Tropical Africa (Maputo)

The considered quantity is not Utilizability, but the monthly available energy above given thresholds, $b . H_{T}$. That makes possible the comparison of methods for which precise definition of "utilizability" is not exactly homogeneous (12) with the others. Auailable energy above various critical intensities is computed, first from these original measured data for thresholds Ic $=0,100$, 200 to $600 \mathrm{~W} / \mathrm{m}^{2}$ and, secondly, using various utilizability methods (only taking, as an input, the mean monthly sum of global irradiation on a horizontal plane and, if available, on the tilted olane). For a given location, plane and Deriod (one month or the whole year) different comparison criteria have been selected: Mean bias error (all thresholds) and Root mean square error (RtiSE) (or Standard-deviation of errors) (all thresholds). Both these parameters are given as relative values (divided by the mean available energy for all thresholds from 0,100 to $600 \mathrm{~W} \cdot \mathrm{m}^{-2}$ ). The relative error on the available energy is also given for one specific threshold $\left(200 \mathrm{~W} \cdot \mathrm{m}^{-2}\right)$.

\section{RESULTS FOR HORIZONTAL PLANES}

Results are ouite homogeneous within each groud. Four methods $(1,2,4,6)$ give very satisfactory results in group 1 (Southern Europe): Mean yearly bias error for all thresholds within 2\%; relative errors for monthly available energy within 3 to 8\% at low thresholds (Tables 2-3); largest errors in winter. Algorithms (3) and (5) show important discrepancies (10 to 20\% in average; 1 arge errors in winter, uD to $30 \%$ for (3)). For the third group (Maputo), all methods seem acceptable (with the exception of (3) in winter), but with systematic underestimate. For group 2 (characterized by more cloudy conditions and small values of clearness index $K_{T}$ ), method (6) gives good results; methods (1-2) offer a satisfactory accuracy, al though with some systematic overestimate (within $10 \%$ at low thresholds). Methods $(3,5)$ show larger errors.

\section{RESULTS FOR TILTED PLANES}

Two types of comparison have been made: first, using only as input the mean monthly irradiation on a horizontal surface; the mean monthly irradiation on the tilted plane is computed by ( 8 ), except for method (1). Second, the $r i g h t$ value on the tilted plane is introduced, except for (1). Bourges method ( 6 ) has not been tested.

In the first case, errors are important, due to a systematical underestimation
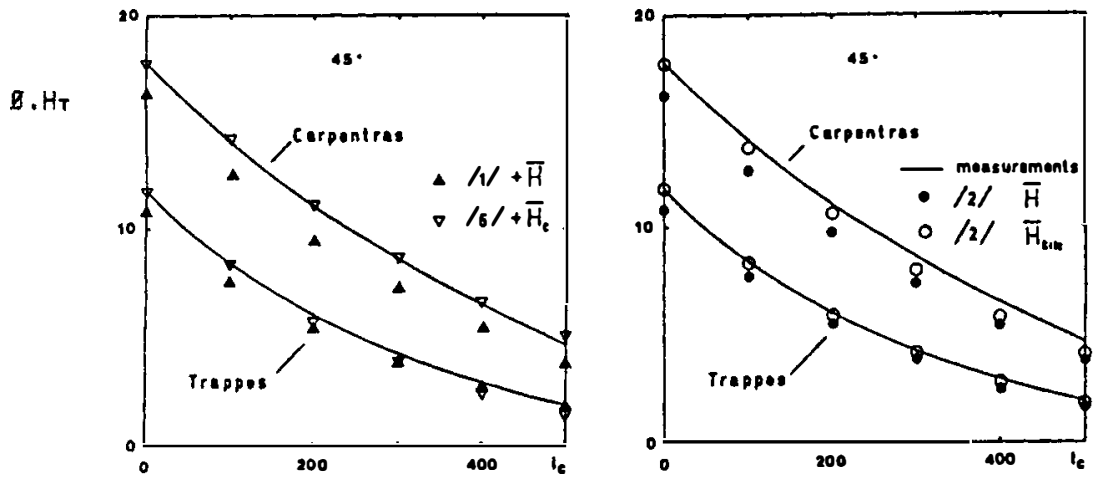

Fig. 1: Available energy $8 . H_{T}(M J / m 2 / d a y)$ above threshold irradiance Ic. 
Table 2: Computation of Available Solar Energy above Threshold Radiation Intensities from 0 to $600 \mathrm{~W} \cdot \mathrm{m}^{-2}$ (Horizontal plane) using different methods. This table gives, for each method, the mean relative bias error and the monthly root mean square error (between brackets) (in \% of the average Available Energy).

\begin{tabular}{|c|c|c|c|c|c|c|}
\hline Station & $\begin{array}{c}\text { Col.Per } \\
/ 1 /\end{array}$ & $\begin{array}{c}C l a r k \\
/ 2\end{array}$ & $\begin{array}{c}\text { Evans } \\
/ 3 /\end{array}$ & $\begin{array}{c}\text { Klein } \\
/ 4 /\end{array}$ & $\begin{array}{c}\text { Gordon } \\
/ 5 /\end{array}$ & $\begin{array}{c}\text { Bourges } \\
/ 6 /\end{array}$ \\
\hline Nice & $\begin{array}{l}-1.6 \\
(2.3)\end{array}$ & $\begin{array}{c}0.9 \\
(2.6)\end{array}$ & $\begin{array}{c}8.4 \\
(6.8)\end{array}$ & $\begin{array}{c}1.1 \\
(2.7)\end{array}$ & $\begin{array}{l}-5.5 \\
(5.2)\end{array}$ & $\begin{array}{l}-0.9 \\
(1.8)\end{array}$ \\
\hline Miliau & $\begin{array}{l}-1.8 \\
(2.4)\end{array}$ & $\begin{array}{c}0.2 \\
(1.7)\end{array}$ & $\begin{array}{c}5.6 \\
(6.5)\end{array}$ & $\begin{array}{c}1.2 \\
(2.7)\end{array}$ & $\begin{array}{l}-6.2 \\
(5.2)\end{array}$ & $\begin{array}{l}-0.8 \\
(1.3)\end{array}$ \\
\hline Carpentras & $\begin{array}{l}-1.9 \\
(2.3)\end{array}$ & $\begin{array}{l}0.5 \\
(1.6)\end{array}$ & $\begin{array}{c}8.4 \\
(6.6)\end{array}$ & $\begin{array}{c}0.5 \\
(2.6)\end{array}$ & $\begin{array}{l}-5.1 \\
(5.0)\end{array}$ & $\begin{array}{l}-0.2 \\
(1.9)\end{array}$ \\
\hline Lisboa & $\begin{array}{l}-0.3 \\
(1.7)\end{array}$ & $\begin{array}{c}2.2 \\
(2.5)\end{array}$ & $\begin{array}{c}8.6 \\
(7.2)\end{array}$ & $\begin{array}{c}1.9 \\
(2.0)\end{array}$ & $\begin{array}{l}-2.8 \\
(2.6)\end{array}$ & $\begin{array}{l}1.7 \\
(1.7)\end{array}$ \\
\hline Trappes & $\begin{array}{c}3.3 \\
(6.5)\end{array}$ & $\begin{array}{c}4.3 \\
(4.3)\end{array}$ & $\begin{array}{r}7.2 \\
(7.0)\end{array}$ & $\begin{array}{c}6.9 \\
(6.6)\end{array}$ & $\begin{array}{l}-6.0 \\
(6.2)\end{array}$ & $\begin{array}{c}0.3 \\
(1.7)\end{array}$ \\
\hline Kilkenny & $\begin{array}{c}4.2 \\
(6.1)\end{array}$ & $\begin{array}{c}4.5 \\
(4.7)\end{array}$ & $\begin{array}{l}10.6 \\
(9.5)\end{array}$ & $\begin{array}{r}7.2 \\
(7.3)\end{array}$ & $\begin{array}{l}-4.0 \\
(4.5)\end{array}$ & $\begin{array}{c}2.7 \\
(3.2)\end{array}$ \\
\hline Maputo & $\begin{array}{l}-4.8 \\
(2.8)\end{array}$ & $\begin{array}{l}-2.1 \\
(2.8)\end{array}$ & $\begin{array}{c}1.7 \\
(7.3)\end{array}$ & $\begin{array}{l}-2.5 \\
(2.8)\end{array}$ & $\begin{array}{l}-6.7 \\
(4.6)\end{array}$ & $\begin{array}{l}-2.7 \\
(2.4)\end{array}$ \\
\hline
\end{tabular}

Table 3: Relative errors (\%) on the computed value of available energy above the threshold irradiance $I_{c}=200 \mathrm{~W}^{-\mathrm{m}^{-2}}$.

\begin{tabular}{lcrrrrrr}
\multirow{2}{*}{ Station Period } & $/ 1 /$ & $/ 2 /$ & $/ 3 /$ & $/ 4 /$ & $/ 5 /$ & $/ 6 /$ \\
\multirow{2}{*}{ Nice } & Year & -2.3 & -0.1 & 7.3 & 0.6 & -5.7 & -0.6 \\
& June & -1.9 & -1.3 & 3.7 & 0.9 & -5.6 & -1.9 \\
& Dec. & -7.7 & -3.1 & 32.1 & -4.7 & -17.6 & -3.5 \\
\multirow{3}{*}{ Kilkenny } & Year & 1.3 & 5.7 & 15.1 & 8.4 & -4.9 & 2.7 \\
\multirow{4}{*}{ Maputo } & June & 1.3 & 3.9 & 10.6 & 7.7 & -3.3 & 1.7 \\
& Year & -5.8 & -3.7 & -0.3 & -3.0 & -7.1 & -3.5 \\
& June & -6.9 & -5.0 & 9.0 & -6.2 & -8.7 & -3.2 \\
& Dec. & -4.6 & -3.3 & -3.4 & -1.4 & -6.1 & -3.4
\end{tabular}

of the mean monthly irradiation ( 3 to $17 \%$, the biggest in winter, see Tab. 4). For low thresholds values ( Ic $=200 \mathrm{~W} \cdot \mathrm{m}^{-2}$ ), errors are within $25 \%$ for method $12 /$, within $30 \%$ for $/ 1 /$. All other methods show errors within $50 \%$ or larger, particularly for vertical planes (Table 5). When the correct average irradiation value is introduced, results are better (Tab. 5): e.9. for $/ 2 /$ the mean bias error for all threstiolds is reduced by 6 to $11 \%$, but monthly errors for a given threshold ( $c=200$ ) are stil! important (10\% at $45^{\circ}$; $20 \%$ to $25 \%$ for vert. surfaces). Methods (3-5) cannot be applied for vert. planes. Method (5) seems to be more reliable for sunny climates.

\section{CONCLUSIONS}

As a general result, all methods have significant errors when the mean monthly irradiation value on the considered plane is not known: within 30\% for reasonably low thresholds, with systematical underestimation for methods $/ 1 /$ and /2/; still larger for other methods. When this value is known, available energy may be computed on a more accurate way, but nonnegiigible errors still remain swithin 20\%, with the most general, and also the most complicate, method /2/). Method (3) (developped for inclined surfaces with tilt angle close to some optimum) and methods (4) and (5) are acceptable for tilt-angles close to 
the latitude, but are not quite reliable for other angles. Some additiorina! work seems to be necessary in order to get a simple method for computing the mean monthly irradiation on a tilted plane and simple empirical utilizability formulas of a general use, for any south-oriented surface.

\section{REFERENCES}

1. M. Collares-Pereira and A. Rabl, A simple procedure for predicting longterm average performance of nonconcentrating and of concentrating solar collectors. Solar Energy, 23, 235 (1979).

2. D.R.Clark, S.A.Klein and W.A.Beckman, Algorithm for evaluating hourly radiation utilizability function. ASME J. of Sol. Energy Eng., 103, 281 (1983).

3. D.L.Evans: T.T.Rule and B.D.Wood, A new look at long-term collector performance and utilizability. Solar Energy, 28, 13 (1982).

4. J.C.Theilacker and S.A.Klein, Improvements in the utiiizability relationshids. Presented at the AS/ISES Meeting, Phoenix, 271 (1980).

5. J.M.Gordon and Y.Zarmi. The utilizability function: 1.Theoretical development of a new approach. and 2. Validation of theory against data-based correlations. Solar Energy, 31, 529 and 537 (1983).

6. B.Bourges and F.Lasnier, Statistical distribution of solar radiation: cumulative frequency curves. Preparation of a european data set. CEC-Report ESF-008-F (1983).

7. S.A.Klein and W.A.Beckman, Review of solar radiation utilizability. ASME Journal of Sol. Energy Eng., 106, 393 (1984).

8. S.A.Klein and J.C.Theilacker. An algorithm for calculating monthly average radiation on inclined surface. ASME J. of Sol. Energy Eng.. 103, 29 (1981).

Table 4: Relative error (\%) on the computed value of the mean daily irradiation on tilted planes.

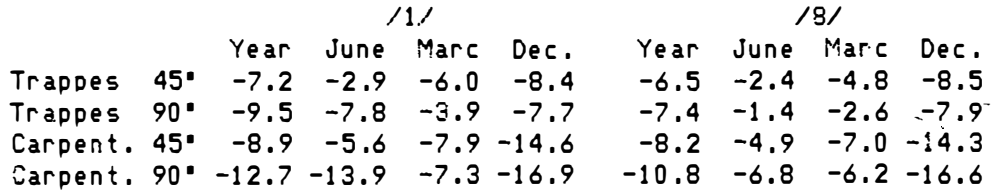

Table 5: Relative errors ( $\%$ ) on the computed value of available energy above the threshold irradiance $I c=200 \mathrm{~W} \cdot \mathrm{m}^{-2}$ on tilted planes, according to the type of input data: $H_{H}$ emonthly average of daily global irradiation on a horizontal plane) or $H_{T}$ (idem on tilted plane).

\begin{tabular}{|c|c|c|c|c|c|c|c|c|c|c|c|}
\hline tation & Tilt & Period & $\begin{array}{l}\text { InDu } \\
/ 1 /\end{array}$ & $\begin{array}{l}\text { data } \\
/ 2\end{array}$ & $/ 3 /$ & 141 & $\begin{array}{r}H_{N} \\
/ 5 /\end{array}$ & 121 & $\begin{array}{l}\text { dat } \\
/ 3{ }^{\prime}\end{array}$ & 141 & $\begin{array}{r}\mathrm{H}_{\mathrm{T}} \\
/ 5 /\end{array}$ \\
\hline rappes & $45^{\circ}$ & $\begin{array}{l}\text { Year } \\
\text { June }\end{array}$ & $\begin{array}{r}-10.4 \\
4.6\end{array}$ & $\begin{array}{r}-8.6 \\
6.3\end{array}$ & $\begin{array}{l}-2.4 \\
12.7\end{array}$ & $\begin{array}{r}-13.2 \\
6.3\end{array}$ & $\begin{array}{r}-11.5 \\
10.0\end{array}$ & $\begin{array}{r}-2.4 \\
8.9\end{array}$ & $\begin{array}{r}4.3 \\
15.5\end{array}$ & $\begin{array}{r}-7.3 \\
9.0\end{array}$ & $\begin{array}{l}-5.5 \\
12.8\end{array}$ \\
\hline rappes & $90^{\circ}$ & $\begin{array}{l}\text { Dec. } \\
\text { Year } \\
\text { June }\end{array}$ & $\begin{array}{r}-0.4 \\
-17.3 \\
10.3 \\
-0.5\end{array}$ & $\begin{array}{r}-5.2 \\
-20.6 \\
8.4\end{array}$ & $\begin{array}{r}-6.8 \\
5.1 \\
78.3 \\
-4.3\end{array}$ & $\begin{array}{r}-34.6 \\
-31.8 \\
11.4 \\
-49.0\end{array}$ & $\begin{array}{r}-49.2 \\
-20.5 \\
59.7 \\
-58.0\end{array}$ & $\begin{array}{r}3.5 \\
-13.9 \\
9.9 \\
-8.6\end{array}$ & $\begin{array}{r}1.9 \\
13.9 \\
80.7 \\
3.8\end{array}$ & $\begin{array}{r}-28.5 \\
-26.3 \\
13.0 \\
-44.6\end{array}$ & $\begin{array}{r}-45.4 \\
-13.8 \\
62.0 \\
-54.7\end{array}$ \\
\hline aroent. & $45^{\circ}$ & $\begin{array}{l}\text { Year } \\
\text { June }\end{array}$ & $\begin{array}{r}-0.3 \\
-13.8 \\
-6.3 \\
-25.4\end{array}$ & $\begin{array}{r}-12.1 \\
-6.5 \\
-20.5\end{array}$ & $\begin{array}{r}-4.3 \\
-6.3 \\
0.9 \\
-17.8\end{array}$ & $\begin{array}{l}-49.0 \\
-15.1 \\
-10.8 \\
-26.5\end{array}$ & $\begin{array}{r}-8.0 \\
-8.5 \\
1.2 \\
-20.7\end{array}$ & $\begin{array}{l}-0.0 \\
-4.4 \\
-1.6 \\
-7.2\end{array}$ & $\begin{array}{r}5.0 \\
1.9 \\
6.1 \\
-4.1\end{array}$ & $\begin{array}{r}-44.0 \\
-7.6 \\
-6.2 \\
-14.3\end{array}$ & $\begin{array}{r}4.8 \\
-0.5 \\
6.4 \\
-7.5\end{array}$ \\
\hline arpent. & $90^{\circ}$ & $\begin{array}{l}\text { Year } \\
\text { June } \\
\text { Dec. }\end{array}$ & $\begin{array}{l}-23.0 \\
-22.9 \\
-29.8\end{array}$ & $\begin{array}{l}-20.9 \\
-15.1 \\
-25.3\end{array}$ & $\begin{array}{r}2.0 \\
59.7 \\
-18.4\end{array}$ & $\begin{array}{l}-30.6 \\
-46.4 \\
-32.7\end{array}$ & $\begin{array}{r}-9.1 \\
53.2 \\
-25.3\end{array}$ & $\begin{array}{r}-10.8 \\
-8.9 \\
-10.4\end{array}$ & $\begin{array}{r}-14.5 \\
71.3 \\
-2.3\end{array}$ & $\begin{array}{l}-21.6 \\
-42.5 \\
-19.3\end{array}$ & $\begin{array}{r}2.2 \\
64.3 \\
-10.4\end{array}$ \\
\hline
\end{tabular}

